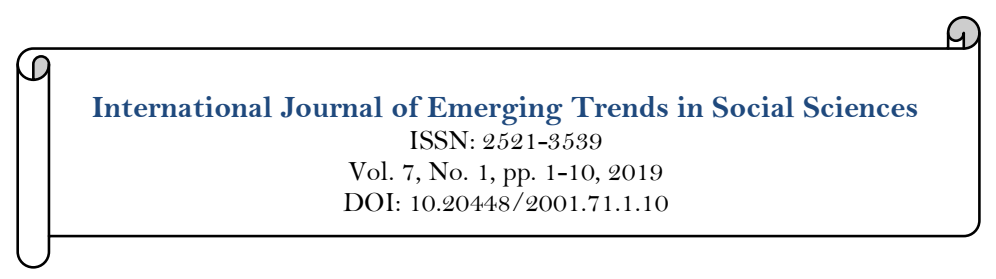

Uupdates

\title{
Strategic Orientation and Organizational Ambidexterity Practices of Mobile Communication Firms in Port Harcourt
}

\author{
Wegwu, Macaulay Enyindah \\ Lecturer, Department of Management, Faculty of Management Sciences, University of Port Harcourt, Nigeria. \\ Email:enyizumac@yahoo.com
}

\begin{tabular}{l|l}
\multicolumn{3}{|c}{ Abstract } & \\
The purpose of the study was to investigate the relationship between strategic & Keywords: \\
orientation and organizational ambidexterity practices of mobile & Ambidexterity practices \\
communication firms in Port Harcourt. One research question was asked & Organisational ambidexterity \\
deemed very important and one hypothesis was also tested. A sample size of & Strategic orientation \\
112 was used from a population of 162 employees which consisted of 4 top & \\
level managers, 37 middle level managers and 121 supervisors in the & \\
regional offices of four mobile communication firms in Port Harcourt. A & Licensed: \\
cross-sectional survey technique was adopted, questionnaire distributed and & This work is licensed under a \\
data generated were analyzed using Pearson Product Moment Correlation & License. \\
Coefficient. Result revealed that strategic orientation has significant & Publisher: \\
relationship with organisational ambidexterity. It was therefore & Scientific Publishing Institute \\
recommended that strategic orientation of the firms should be predicted on & Accepted: 12 November 2019 \\
the dynamics of market competitiveness and the environment to effectively & Published: 27 November 2019 \\
influence organizational ambidexterity. &
\end{tabular}

Funding: This study received no specific financial support.

Competing Interests: The author declares that there are no conflicts of interests regarding the publication of this paper.

\section{Introduction}

In the work of Grover and Saeed (2004) they contended that strategic orientation is the exploitation of means in achieving a market advantage. They further maintained that the broad orientation on exploitation extends to the decisions on the scope of the dealing which includes a portion of the characteristics of the market items and the geographic area of the institution. The key understanding of strategic orientation it is that it is the instrument that can be utilized by a business to generate an alliance with that which it is capable of doing to that which it wants to achieve. Strategic orientation of companies is the reflection of the strategic directions implemented by an organisation to generate the proper and enabling environment for the continuous realistic functioning of the institution (Gatignon \& Xuereb, 1997).

Strategic orientation vary by the speed of transformation in the organisational domain. Miles, Snow, Meyer, and Coleman (1978) identified three strategic types in organisations: Defenders, aggressors and proactors. Any adopted strategic orientation is always understood to be radically distinctive without equal as it is related to the chosen market and each orientation has consistently been reflected particularly through technology, arrangement and course of action that is in alignment with the market strategy. The fourth strategic orientation of companies is the reactor. Despite its being, there are inconsistencies in the application of the strategy, technology, arrangement and course of action. Absolutely, the emphasis of this research therefore still remains on the three earlier identified strategies of defenders, aggressors and pro-actors.

Varying literatures on organisational issues state that a company is successful when it efficiently aligns with the administration of today's business, while it simultaneously adapts to ecological changes (Duncan, 
1976). By dint of this assertion, he became the first to coin the term organisational ambidexterity in firms. However, it is March (1991) that is admirably acknowledged and seen as the mover of interest for today's academics concern in organisational ambidexterity in firms ever since he introduced the concept of exploitation and exploration which has gained momentum in research and practice (Raisch \& Birkinshaw, 2008).

In any case, March (1991) is of the view that the accomplishment of a business depends on a company's ability to balance exploitation of already known competencies and exploration of novel opportunities. While exploitation is referring to unavoidable additional improvement, the latter refers to fundamental innovation (Enkel, Heil, Hengstler, \& Wirth, 2015). It is obviously accepted that both perspectives require essentially dissimilar mind-sets, different infrastructures, different cultures, processes and learning performance with which companies have to separate their attention and resources (March, 1991; Raisch \& Birkinshaw, 2008; Tushman \& O'reillyIii, 1996).

While exploitation includes variables such as "being effective without wasting time, highly developed state of perfection, choice and accomplishment of strategic decisions, exploration is connected with activities such as "looking for possibilities, variations in idea, testing of an idea or uncovering something. By dint of the associated variables, several scholars are of varying opinions which supports that there exists evidence of compromise between aligning an institution's capability to exploit active competencies and uncovering new ones (Raisch \& Birkinshaw, 2008) since this involves different skills and highly developed different management competencies that might make contemporary existing businesses obsolete (Hannan \& Freeman, 2008; He \& Wong, 2004).

A later conceptualization by Gibson and Birkinshaw (2004) complemented this observation with empirical evidence that ambidexterity also stems from an institutional unit's supportive circumstance. Of recent, scholars had taken resolute on the role of connecting the possible mechanisms that should be in place between exploitation and exploration units as well as the leadership features that are capable of assisting in dealing with the tensions arising (Lubatkin, Simsek, Yan, \& Veiga, 2006; Smith \& Tushman, 2005). It has been noted that additional investigations on exploration or exploitation tensions had questioned the inbuilt opposing views between exploitation and exploration, and had proved that both functions can be treated either as two ends on a scale or as not pertinent to each other depending on the focus on a single or numerous levels of investigation (Gupta, Smith, \& Shalley, 2006).

O'Reilly and Tushman (2008) posited unanimously that ambidexterity which involves the capacity of a firm to simultaneously or successively explore and exploit, enables an institution to become accustomed over time. Ambidexterity is not only a subject of institutional arrangement, but refers to "the routines and processes by which ambidextrous institutions assemble, harmonise, combine conflicting hard work, assign, reassign, join, and re-join resources and assets across separated exploratory and exploitative units" (Jansen, Tempelaar, Bosch, \& Volberda, 2009a). As a consequence, ambidexterity is a dynamic capability of an institution that enables them to incessantly transfer their management of exploitation and exploration functions over time, depending on the short and long term market needs (Jansen et al., 2009a; O'Reilly \& Tushman, 2008).

\subsection{Purpose of the Study}

To investigate the relationship between strategic orientation and organizational ambidexterity of mobile communication firms in Port Harcourt.

\subsection{Research Question}

What is the relationship between strategic orientation and organisational ambidexterity of mobile communication firms in Port Harcourt?

\subsection{Research Hypothesis}

The research hypothesis stated in the null form is that there is no significant relationship between strategic orientation and organizational ambidexterity of mobile communication firms in Port Harcourt.

\section{Review of Literature}

\subsection{Organisational Ambidexterity}

Following the mixture of remarkable developments that have been studied under the unifying concepts of exploitation and exploration, Lavie, Stettner, and Tushman (2010) asserts that a study on the tensions of ambidexterity would not be complete unless the real idea of exploitation and exploration under study was carefully defined. According to Tushman and O'reillyIii (1996) ambidextrous institutions are those that possess the inclination to manage different successive innovation events simultaneously. Notably indeed, as institutions need to adapt to complex and ever changing market competitiveness, the very idea on ambidexterity is increasingly related to tensions which are observed to be coming from the desire for institutional adaptation to the environmental changes (Ingram, Lewis, Andriopoulos, \& Gotsi, 2008). 
O'Reilly and Tushman (2008) posited unanimously that ambidexterity involves the capacity of a firm to simultaneously or successively explore and exploit, enables an institution to become accustomed over time. Ambidexterity is not only a subject of institutional arrangement, but refers to "the routines and processes by which ambidextrous institutions assemble, harmonise and combine spread conflicting hard work, assign, reassign, join, and re-join resources and assets across separated exploratory and exploitative units" (Jansen et al., 2009a).

From the asserted views by scholars, exploitation and exploration are seen to have autonomous processes, where both performances can be maintained by organisations without any desire to accomplish a balance between the two (Gupta et al., 2006; Lubatkin et al., 2006). Writers such as Cao, Gedajlovic, and Zhang (2009) have made inquiries into exploitation and exploration to uncover the relevant conceptual dissimilarity when they examined in speech or writing about the balance and the collective dimension of ambidexterity. In acknowledgement of the balanced view, exploitation and exploration are observed to be at the two ends of the same scale, fundamentally existing as denying the reality in a trade- off circumstances. Looking at it from the other angle, the collective dimension of ambidexterity, which argues against the inbuilt state of emotional strain stuck between exploitation and exploration, sees them as sovereign and not relevant to each other such that institutions can chase both at an elevated height without determining to accomplish any equilibrium.

\subsection{Organisational Ambidexterity Practices}

Even though there exist different opinions from writers on the difficulty involved in attaining both exploitation and exploration, it is believed that there still exist numerous promising approaches justifiably accepted by scholars as identified in literatures which could aid in attaining organisational ambidexterity in firms (Raisch \& Birkinshaw, 2008). In the first instance, it is recommended that institutions can develop specific required structures that are capable of lessening the seriousness of the tensions between exploitation and exploration activities. Structural ambidexterity can be realised by the creation of a distinctive and spatial structures (Gibson \& Birkinshaw, 2004). The idea of spatial separation involves the creation of different business units that will be engaged in the pursuit of exploitation and exploration.

In all, the contradictory demands of exploitation and exploration and the argument of not reaching a compromise in one at the cost of the other have always pre-occupied the attention of researchers in various literatures on institutional learning (Levinthal \& March, 1993; March, 1991) and strategic management (Lubatkin et al., 2006; Markides \& Charitou, 2004) technological innovation (Gary, 2003; He \& Wong, 2004) institutional design (Graetz \& Smith, 2005; Jensen, Luthans, Lebsack, \& Lebsack, 2005) institutional theory (Benner \& Tushman, 2003) and institutional behaviour (Gibson \& Birkinshaw, 2004). All of the above have explained the reality and the imperative of managing conflicting demands in increasingly competitive and continuously changing markets and have also afforded a rich impression of the different types of tensions that emerge in pursuing both exploitation and exploration.

The over-riding concern for balancing both becomes more challenging given that innovation is a function of creative thinking and exploratory actions, whereas efficiency is related to routine performance and exploitation of skills and knowledge Bledow, Frese, Anderson, Erez, and Farr (2009).

Multiple approaches have been suggested by the literature on how institutions build an ambidextrous capability or how these tensions are managed have remained largely unexplored (Bledow et al., 2009) (Cantarello, Martini, \& Nosella, 2012). Remarkably, the two level approaches of the underlying thesis which are both the institutional and individual level allows us to explore how these tensions are run down throughout the institution, how these are supposed and eventually managed following a stream of research on innovation as a process rather than an outcome (Brion, Mothe, \& Sabatier, 2010; He \& Wong, 2004).

Predicated on March (1991) explanation of exploitation and exploration as involving separate and conflicting learning processes, investigations on ambidexterity had viewed exploitation and exploration as having two ends of the same scale, challenging for scarce resources and realized through conflicting institutional capabilities. In this circumstance, ambidexterity is conceptualized as managing the tensions and conflicts that arise from these functioning to discover the suitable balance between the two.

From the asserted views by scholars, exploitation and exploration are seen to have autonomous processes, where both performances can be maintained by organisations without any desire to accomplish a balance between the two (Gupta et al., 2006; Lubatkin et al., 2006). Writers such as Cao et al. (2009) have made inquiries into exploitation and exploration to uncover the relevant conceptual dissimilarity when they examined in speech or writing about the balance and the collective dimension of ambidexterity. In acknowledgement of the balanced view, exploitation and exploration are observed to be at the two ends of the same scale, fundamentally existing as denying the reality in a trade- off circumstances. Looking at it from the other angle, the collective dimension of ambidexterity, which argues against the inbuilt state of emotional strain stuck between exploitation and exploration, sees them as sovereign and not relevant to each other such that institutions can chase both at an elevated height without determining to accomplish any equilibrium.

The main proposal for balancing exploitation and exploration is by simultaneously pursuing both by using different structural and contextual approaches as subsisting units in achieving organisational ambidexterity. However, O'Reilly and Tushman (2008) had uncovered evidences in support of the 
manifestation of different units. It also requires different competencies, skills, knowledge and behavioural patterns with each complementing another by dint of strategic intent. From the foregoing, it can be interpreted to mean that the major expectation of ambidexterity is to exploit opportunities through simultaneously undergoing exploitation and exploration actions which requires much more of leadership than structural concern (Smith \& Tushman, 2005). General results on structural ambidexterity has demonstrated that it consists of autonomous units for investigation and exploration with the leadership that could manage the emotional stress connected with realising possible adjustments, Jansen et al. (2009a).

\subsection{Market Orientation and Organisational Ambidexterity}

Contextual ambidexterity could be defined as the individual behavioural tendencies that simultaneously permit or support the alteration and adjustment to dynamic environmental issues affecting firms. The tension involved in accomplishing exploitation and exploration through structural ambidexterity had been observed to be resolved through contextual ambidexterity by Gibson and Birkinshaw (2004) at the individual level involving individual interactions and consciousness towards making choices on time required for both adjustments and adaptability.

According to studies by Gibson and Birkinshaw (2004) they measured adjustment and adaptability on a 3item scale in light of generated data from 41 business units. Their finding revealed that business units that had succeeded more were involved in adjustments and adaptability than the ones which are not fruitful.

Conclusively, irrespective of reviewed studies and explanations on how to attain ambidexterity, empirical findings have uncovered evidences in support of the best concept underlying the accomplishment of ambidexterity to be the dynamic capability of firms which includes the utilization of a comprehension of both outer and inner environmental factors for formulation of institutional strategies.

\subsection{Strategic Orientation}

Research in the area of strategic management has addressed the way in which strategic orientation of companies should be considered, based on vigorously considered results of numerous perspectives. The absolute choice to track a strategic behaviour or another occurs as a result of the divergence of the environments diverge from the settings presented and legally valid over the years. Thus, an explanation of the penalty on performance of strategically oriented institutions is required. Subject to the above, strategic orientation of companies represents the summation of all directions that influence the company's marketing strategy and all the strategic implementation activities (Noble, Sinha, \& Kumar, 2002).

Most studies persistence on the knowledge of strategic orientation of companies was predicated on data obtained from companies that had worked in western countries. Therefore, difficulties appeared when trying to transpose and apply the results and patterns evidenced by these studies on businesses that are working in different environments. Thus numerous studies by Jabnoun, Khalifah, and Yusuf (2003); Kirca, Ramachandran, and Bearden (2005); O'Regan and Ghobadian (2005) make obvious the fact that the sound effects of strategic orientation of companies are predicated on the dynamics of the market competitiveness. Because of this environmental dynamic, studies completed in developed economies are largely ambiguous. What could assist for a deeper comprehending of strategic orientation of companies might as well be the tradition of an institution that was distinct throughout investigation as a pattern of values and shared ideas that help employees understand how the institution functions, thus ensuring a guide for their behaviours relative to a company.

The relevant investigations dedicated to resource-based perspective (Blumentritt \& Danis, 2006; Paladino, 2008) was based on how firms develop distinctive sets of capabilities, assets that over time, become a source of competitive advantage. These resources, capabilities and skills are obtained through well-organized processes and possess the characteristic of being unique and difficult to imitate by competitors. By dint of resource based perspective, it is acknowledged that a firm's resources and unique capabilities are the deciding factors regarding the type of strategic orientation of companies and performance level of an enterprise (Barney, 1991; Paladino, 2008).

The unique capabilities of a firm, if nourished, sustained and strengthened, can assist the organisation in achieving a market advantage over its rivals. Also (Hafeez, Zhang, \& Malak, 2001) indicate that capabilities are synonymous with core competence, if the previous is "strategically valuable" contributing to an organisation's drive towards meeting up with its objectives. There is a school of thought that believes that capabilities are a part of resources that include physical possessions (such as raw materials and equipment), human resources (such as training, experience and skills), and also as organisational resources in the form of processes and routines (Barney, 1991; Marino, 1996). Stating in a different way, several authors argue that capabilities need to be kept separate from resources as the former is more dynamic. Hafeez et al. (2001) agree with the second argument.

\subsection{Strategic Types}

There exists different habit of classifying business strategies. The reality however is that the actual appraisal of strategies depends completely on the height of aggressiveness which is founded on the position of 
the market, the level of risks involved, the financial position of the firm, product innovation inclinations and the independence in taking decisions. From the description above, strategic aggressiveness is a business strategy that also can be used to match the level of aggressiveness undertaken by a firm in view of the market situation they found themselves. This can be stated to mean that at any given point in time, a business organisation is obsessed with considering its marketing position in terms of domination by engaging aggressiveness strategy.

Prospector Strategy: Firms that pursue prospector strategy are highly innovative and always occupied with identifying new markets and new opportunities. Their major pre-occupations, whole commitments and orientations are towards achieving growth and taking all reasonable and payable risks. The prospectors are known to be involved in more aggressive strategy than all the other strategies. The prospector's strategy includes an active and consistent pursuit of opportunities in untapped market and the development of new products. This strategy enables the prospector to use marketing aggressiveness in order to take advantage of customers from competitors, continually searching for available opportunities and be the earliest in the market. More often, a reasonable number of their incomes are derived from new products or from identified new markets. Their interest in trying to be earliest in the market is reliant upon their thinking that as first strategic actors, it will motivate them to benefit from providing opportunities with respect to high margin. In any industry they operate, they will prefer to be in the introductory or expansion stage. The implication of this is a proof that the company has enormous strength with strong opportunities that are pronounced in the environment. This prospector strategy makes for good expansion and development.

A very strong strategy for competition is built through various methods of marketing mix. That is basing its marketing strategy on the quantity of response from customers concerning their needs. An orderly arrangement of the gains from the utilization of this strategy includes exploitation of opportunities, maintaining relative market position, taking advantage of other institution to maximise profits and laying more emphasis on competitive products. Obviously, the strategy fails to require any form of market research analysis.

Defender Strategy: Individual firms that make use of this strategy are not vigorously concerned with aggressive marketing spirit or have the desire for expansion but are mainly involved in identifying and maintenance of relatively market stability. Implication of this is that defenders have the utmost desire to possibly reduce the rate of change witnessed in the market and more especially remain relaxing with current operations, get rid of the influence of threats, and maintain its financial rate of returns in order to consistently achieve its profit motives and in the short-run, secure debt paying ability. The defenders, in trying to maintain its stable market, strive to continue with their on- going prices, reduce the cost of advertising and promotional activities, vigorously exhibit inadequate quantity of products that are of good qualities to their customers. The defenders are mainly known to operate in industries that make use of relatively matured and sophisticated technological efficiency. In the event of any possible environmental threats or weaknesses, they have no option than to go into liquidation.

Analyser Strategy: The understanding of the analyser strategy is that it makes provision for an extension of full marketing research and analysis geared in the direction of reducing risk, overcome the pressure of competitors and for the maintenance of stable revenue generation. The availability of the data from the market research is achieved through information gathering from the surroundings of the institutions in a bid to obtain benefits and keep up with the current functioning of the institutions.

The analyst manager tends to completely avoid investing in new markets or products that would not ensure certainty of success by dint of risk and unavailable information.

The analysis is done in consideration of the trade-off between the defenders and prospectors in order to ensure taking risks that are less. Very consciously the analyser strategy ensures that fewer mistakes are made than the mistakes identified from the prospector strategy. The analyser strategy fails to strongly make provision for the stability of their institutions than the defender strategy does. Most institutions adopt the analyser strategy which is intended for the expansion of their core competencies. Rather than being concerned with the development of completely new products, they prefer making incremental improvements on the existing products, instead of expansion. This development is responsible for watching the rationale for development closely in other industries in order to be certain of the best suitable time to act. It is similarly a known fact that the analyser expends more analytical and conceptual time in planning than the prospectors. Generally, they tend to expand their customer base than going into new market, thereby maintaining regular income from existing products before the risk of accomplishing new innovations.

Reactor Strategy: With this strategy, an organisation strategically maintains its operational position. The reactor strategy fails to consciously provide for any product strategy, but makes provision for reaction to changes as they happen and consequently are forced to respond because of forces and pressures from the environmental pressures. As a consequence, the reactor strategy is understood to be the least recommended and effective of all the four strategies. According to Ferrier (2001) reactions can only take place only when they have noticed strong competition situation in the economy and expectation of customers have started to have negative consequence on the economic situation of the institutions. 
3. Methodology

3.1. Research Design

The research design that was used in the study was the cross-sectional survey method, more specifically, the quasi-experimental design because of the characteristics of the respondents for the study.

\subsection{Population of the Study}

The population consisted of 4 top level managers, 37 middle level managers and 121 lower level managers from MTN, Globacom, Airtel and 9mobile in their regional offices in Port Harcourt.

\subsection{Sampling Technique}

The selective or the judgmental technique was adopted because it was more convenient for the researcher considering the number of the firms and the size of the respondents.

\subsection{Sample Size Determination}

The sample size of 115 of different categories of respondents used in the research was determined using Taro Yamane formula. However, the exact number used was 112 employees.

\subsection{Data Collection Method}

Data collection method used included administration of questionnaire, personal interview and review of related literature. The researcher distributed a total of 115 copies of the questionnaire and only retrieved 112 from all respondents.

\subsection{Validity and Reliability}

Validity of the instrument for the research was by face and content means, while the reliability of the instrument was subjected to confirmation test of internal consistency method in line with the Cronbach Alpha Test based on the value of 0.7 .

\subsection{Operational Measures of Variables}

The four point likert scale was administered against a set of five questions for the variables.

\subsection{Data Analyses Technique}

Data were collected through primary source which included the use of questionnaire and personal interview. The analysis was carried out with the use of Pearson Product Moment Correlation Coefficient.

\subsection{Decision Criterion}

We rejected the null hypothesis because the probability value $(\mathrm{PV})$ is significant i.e $\mathrm{PV}<0.05$ and accepted the alternate hypothesis.

\section{Discussion of Findings}

4.1. Demographic Section

1. Work experience: Majority of the participants have experiences of less than 10 years.

2. Qualification: It was revealed that the participants have degrees ranging from B.Sc, M.Sc of varying numbers in each of the organisation.
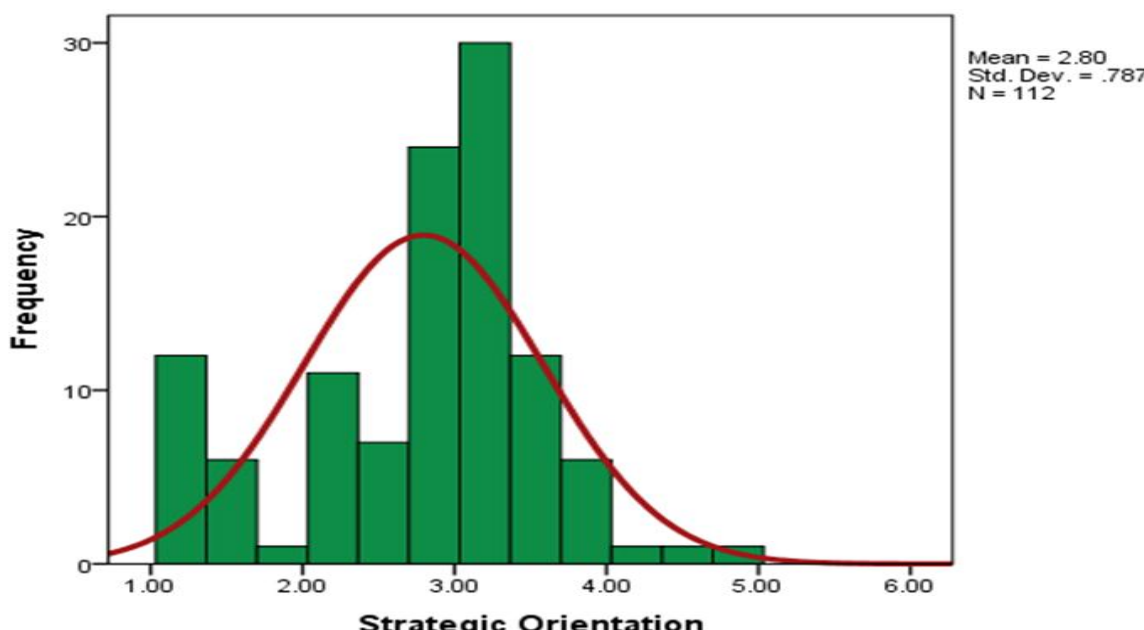

Figure-1. Histogram distribution for strategic orientation of the firms. Source: Researcher's SPSS output, 2019. 
Illustrated in Figure 1 is the histogram depicting the allocation for the predictor variable: strategic orientation of companies? Evidence from the allocation suggests that strategic orientation of companies is seen to be significantly manifested by the mobile communication firms that were examined in this study. The obvious reason is because the average/mean value $(\mathrm{x}=2.80)$ is evidently ascertained to be substantially important in view of the acceptable set base mean value of $\mathrm{x}>2.5$. Therefore, the evidence indicates that orientation inclinations of the examined mobile communication firms can be considered as strategic to the extent that they are aggressive, defensive and also proactive.

Table-1. Distribution for the dimensions of strategic orientation.

\begin{tabular}{c|c|c|c|c|c|c|c}
\hline \multirow{2}{*}{$\begin{array}{c}\text { Strategic } \\
\text { orientation }\end{array}$} & $\mathbf{N}$ & Mean & Std. deviation & \multicolumn{2}{|c}{ Skewness } & \multicolumn{2}{c}{ Kurtosis } \\
\cline { 2 - 8 } & Statistic & Statistic & Statistic & Statistic & Std. error & Statistic & Std. error \\
\hline Aggressive & 112 & 2.8339 & .79589 & -.590 & .228 & .020 & .453 \\
\hline Defence & 112 & 2.7571 & .89218 & -.287 & .228 & -.544 & .453 \\
\hline Proactive & 112 & 2.7964 & .78728 & -.471 & .228 & .327 & .453 \\
\hline Valid N (listwise) & 112 & & & & & & \\
\hline Source: Researcher's SPSS output, 2019. & & & &
\end{tabular}

In Table 1, the aggressive strategic orientation of companies is proved to be the institution's offensive approach and tendency to target the positions and markets of its competitors through price slashes and cuts and is seen to have a significant mean value $\left(\mathrm{x}_{1}=2.8339\right)$ indicating significant levels of proof of manifestation of the dimension. Secondly, the defensive strategic orientation of companies (Defence), which reveals the inclination of organizations for maintaining or protecting its position in the market is also observed to have a significant mean value $\left(\mathrm{x}_{2}=2.7571\right)$. Proactive strategic orientation of companies having the average/mean value of $\left(\mathrm{x}_{2}=2.7964\right)$ reflects the organizations capacity and inclination for planning ahead and taking progressive actions is also revealed to provide evidence of substantial manifested by the mobile communication companies.

The output from the analysis on the dimensions revealed that all the three dimensions of strategic orientation of companies are observed to be significantly manifested by the mobile communication firms with the most dominant feature or strategy linked to aggressiveness $\left(\mathrm{x}_{1}=2.8339\right)$ and the least strategy often adopted linked to defensive strategy $\left(\mathrm{x}_{2}=2.7571\right)$.

Table-2. Distribution for organisational ambidexterity measures.

\begin{tabular}{c|c|c|c|c|c|c|c}
\hline $\begin{array}{c}\text { Organisational } \\
\text { ambidexterity }\end{array}$ & $\mathbf{N}$ & Mean & $\begin{array}{c}\text { Std. } \\
\text { deviation }\end{array}$ & \multicolumn{2}{c}{ Skewness } & \multicolumn{2}{c}{ Kurtosis } \\
\cline { 2 - 8 } & Statistic & Statistic & Statistic & Statistic & Std. error & Statistic & Std. error \\
\hline Exploration & 112 & 2.9857 & .82515 & -.460 & .228 & -.177 & .453 \\
\hline Exploitation & 112 & 2.8339 & .75642 & -.413 & .228 & -.318 & .453 \\
\hline Valid N (listwise) & 112 & & & & & & \\
\hline
\end{tabular}

From Table 2, the results obviously indicate that both measures are practices which are well observed and experienced $\left(\mathrm{x}_{1}=2.9857 ; \mathrm{x}_{2}=2.8339\right)$ by the participants of the research. The results present exploration as comprehensively being a more dominant activity by the mobile communication firms as compared to exploitation thus, suggesting a more commitment of the mobile communication firms on discovering and exploring the opportunities through research activities. This however furthers the declaration for strong levels of competition among the firms in the industry which eventually underscores exploration activities as imperative for competitiveness.

4.2. Test of Hypothesis

Table-3. Test for hypothesis.

\begin{tabular}{|c|c|c|c|c|}
\hline \multicolumn{2}{|c|}{ Hypothesis testing } & 1 & 2 & 3 \\
\hline Defence & Correlation & 1 & & \\
\hline Exploration & Correlation & $.730^{* * *}$ & 1 & \\
\hline Exploitation & Correlation & $.743^{* * *}$ & $.882^{* * *}$ & 1 \\
\hline
\end{tabular}

Source: Spss output, 2019.

Defensiveness and exploration: The relationship between defensiveness and exploration in Table 3 showed that there exists evidence of significant relationship between the research variables given the correlation $(\mathrm{R})$ coefficient of $\mathrm{R}=.730$ with $\mathrm{P}=0.000(\mathrm{P}<0.05)$. The results obviously present defensiveness as a substantial predictor of exploration. In curse of the analysis, the results imply that defensiveness 
contributes to enhancing the manifestations of exploration and in light of this, both variables can be considered as having a significant relationship.

Defensiveness and exploitation: The relationship observed between defensiveness and exploitation revealed that there exists evidence of significant relationship between the research variables given a correlation $(\mathrm{R})$ coefficient of $\mathrm{R}=.743$ with $\mathrm{P}=0.000(\mathrm{P}<0.05)$.

Table-4. Test for hypothesis.

\begin{tabular}{c|c|c|c|c}
\hline \multicolumn{6}{c|}{ Hypothesis testing } & $\mathbf{1}$ & $\mathbf{2}$ & $\mathbf{3}$ \\
\hline Proactive & Correlation & 1 & & \\
\hline Exploration & Correlation & $.844^{* *}$ & 1 & \\
\hline Exploitation & Correlation & $.853^{* *}$ & $.882^{* *}$ & 1 \\
\hline **. Correlation is significant at the 0.01 level (2-tailed).
\end{tabular}

Pro-activeness and exploration: The relationship between pro-activeness and exploration as indicated in Table 4 revealed that there exists evidence of significant relationship between the research variables given the correlation $(\mathrm{R})$ coefficient of $\mathrm{R}=.844$ with $\mathrm{P}=0.000(\mathrm{P}<0.05)$. The results suggest that pro-activeness contributes to outcomes which can be considered as reflecting exploration.

Pro-activeness and exploitation: The relationship between pro-activeness and exploitation revealed that there exists evidence of significant relationship between the research variables given a correlation $(\mathrm{R})$ coefficient of $\mathrm{R}=.853$ with $\mathrm{P}=0.000(\mathrm{P}<0.05)$. The results showed that pro-activeness strategy has a substantial effect on exploitation and therefore contributes strongly to the manifestations of exploitation, hence, both variables can be regarded as having a significant relationship.

\section{Summary}

Strategic orientation of companies in mobile communication firms in Rivers State is significant Here, the research findings that related to the evidence of the manifestations of strategic orientation of companies in the studied mobile communication firms in Rivers State revealed significant evidence and manifestations of all three forms of the dimension: aggressiveness, defensiveness and pro-activeness. It therefore became obvious from the results to propose that orientations which are best described or reflected aggressiveness and proactiveness should be more significant and considered as more applicable within the technologically based firms studied.

An adoption of aggressiveness is acceptable as suggested by the result and therefore strategically advantageous and facilitates a change for the better to the organizations exploitation and exploration of opportunities and resources.

By the foregoing, aggressiveness is obviously viewed as a strategy for engaging in high risk activities which in a way also drives transform and modernization. The aggressive strategy is one which provides a means for market penetration and segment capture. This undisputable drive for relevance and market share is observed to be responsible for engagement of operations which are intended to first seek the organizational placements of brands within their markets before emphasizing on profit motive.

The evidence from the observation reinforces the assertion which was put forward by Desarbo, Di Benedetto, Song, and Sinha (2005) that defensiveness is a strategy which is rather poised to protect current market position and market share. This implies an emphasis of defensive strategy on protecting established market conditions which are considered as advantageous.

\subsection{Conclusion}

Even if findings have proved pro-activeness as a more preferred and recommended strategy occasioned by the unhealthy and often toxic relationships between firms' intra-industry, it was however considered the only best alternative given the characteristic high-end competition between the firms.

Results also proved that aggressiveness has a strong influence on organisational ambidexterity in firms hence, is believed by all the participants in the mobile communication firms as being the most suited for the technologically based firms. This corroborates with the comments of previous scholars who describe the transition and reformation of the telecommunication industry as endearing and encouraging strong competition and aggression between industry players.

There is a substantial indication from the findings that pro-activeness possesses the strongest relationship with organisational ambidexterity in firms and is anticipated to yield a more beneficial relationship and intraindustrial relations between firms and in addition, pro-activeness impacts significantly on exploitation and exploration, allowing for collaboration and partnerships between firms. In other words, evidence from the analysis suggests strong levels of pro-activeness by the mobile communication firms which drives their innovation activities, indicating that often times, market penetration and dominance are pursued through service quality, innovation and pro-activeness. 


\subsection{Recommendations}

i. That ambidexterity practices should involve separate and conflicting learning processes to determine a suitable balance on opposing demands.

ii. There should be separate exploitation and exploration units as well as leadership features capable of dealing with the tensions arising.

iii. There should be an integration of dynamic capability as a panacea for achieving competitive advantage.

iv. Strategic orientation of companies should be adopted to influence all directions of a company's marketing strategy and its implementation activities.

\section{References}

Barney, J. B. (1991). Firm resources and sustained competitive advantage. Journal of Management, 17(1), 99-120. Available at: https://doi.org/10.1177/014920639101700108.

Benner, M. J., \& Tushman, M. L. (2003). Exploitation, exploration, and process management: The productivity dilemma revisited. Academy of Management Review, 28(2), 238-256.

Bledow, R., Frese, M., Anderson, N., Erez, M., \& Farr, J. (2009). A dialectic perspective on innovation: Conflicting demands, multiple pathways, and ambidexterity. Industrial \& Organizational Psychology, 2(6), 305-337. Available at: https://doi.org/10.1111/j.1754-9434.2009.01154.x.

Blumentritt, T., \& Danis, W. M. (2006). Business strategy types and innovative practices. Journal of Managerial Issues, $18(2), 274-292$.

Brion, S., Mothe, C., \& Sabatier, M. (2010). The impact of organisational context and competences on innovation ambidexterity. International Journal of Innovation Management, 14(02), 151-178. Available at: https://doi.org/10.1142/s1363919610002593.

Cantarello, S., Martini, A., \& Nosella, A. (2012). A multi-level model for organizational ambidexterity in the search phase of the innovation process. Creativity and Innovation Management, 21(1), 28-48.

Cao, Q., Gedajlovic, E., \& Zhang, H. (2009). Unpacking organizational ambidexterity: Dimensions, contingencies, and synergistic effects. Organization Science, 6(20), 781-796. Available at: https://doi.org/10.1287/orsc.1090.0426.

Desarbo, W. S., Di Benedetto, C. A., Song, M., \& Sinha, I. (2005). Revisiting the miles and snow strategic framework: Uncovering interrelationships between strategic types, capabilities, environmental uncertainty, and firm performance. Strategic Management Journal, 4(26), 47 - 74. Available at: https://doi.org/10.1002/smj.431.

Duncan, R. B. (1976). The ambidextrous organization: Designing dual structures for innovation. The Management of Organization, 1(9), 167-188.

Enkel, E., Heil, S., Hengstler, M., \& Wirth, H. (2015). Exploratory and exploitive innovation: To what extent do the dimensions of individual level absorptive capacity contribute? Paper presented at the R\&D Management Conference, June 23rd 26th 2015, Pisa, Italy.

Ferrier, W. J. (2001). Navigating the competitive landscape: The drivers and consequences of competitive aggressiveness. Academy of Management Journal, 44(4), 858-877. Available at: https://doi.org/10.5465/3069419.

Gary, L. (2003). Ambidextrous innovation. Harvard Management Update, 8(5), 5-12.

Gatignon, H., \& Xuereb, J. M. (1997). Strategic orientation of the firm and new product performance. Journal of Marketing Research, 34(1), 77-90. Available at: https://doi.org/10.1177/002224379703400107.

Gibson, C. B., \& Birkinshaw, J. (2004). The antecedents, consequences, and mediating role of organizational ambidexterity. Academy of Management Journal, 47(2), 209-226. Available at: https://doi.org/10.2307/20159573.

Graetz, F., \& Smith, A. (2005). Organizing forms in change management: The role of structures, processes and boundaries in a longitudinal case analysis. Journal of Change Management, 5(6), 311-328.

Grover, V., \& Saeed, K. A. (2004). Strategic orientation and performance of internet-based businesses. Info Systems Journal, 14(6), 23-42. Available at: https://doi.org/10.1111/j.1365-2575.2004.00161.x.

Gupta, A. K., Smith, K. G., \& Shalley, C. E. (2006). The interplay between exploration and exploitation. Academy of Management Journal, 49(4), 693-706. Available at: https://doi.org/10.5465/amj.2006.22083026.

Hafeez, K., Zhang, Y. B., \& Malak, N. (2001). Determining key capabilities of a firm using analytic hierarchy process. International Journal of Production Economics, 76(1), 39-51.

Hannan, M. T., \& Freeman, J. (2008). Organizational ecology. Cambridge MA: Harvard University Press.

He, Z. L., \& Wong, P. K. (2004). Exploration vs. Exploitation: An empirical test of the ambidexterity hypothesis. Organization Science, 6(15), 481-494. Available at: https://doi.org/10.1287/orsc.1040.0078.

Ingram, A. E., Lewis, M. W., Andriopoulos, C., \& Gotsi, M. (2008). Innovation tensions and organizational ambidexterity: Toward a collective paradox frame. Paper presented at the Academy of Management Annual Meeting Proceedings.

Jabnoun, N., Khalifah, A., \& Yusuf, A. (2003). Environmental uncertainty, strategic orientation, and quality management: A contingency model. Quality Management Journal, 10(4), 17-13.

Jansen, J. J. P., Tempelaar, M. P., Bosch, V. D. F. A. J., \& Volberda, H. W. (2009a). Structural and ambidexterity: The mediating role of integration mechanisms. Organization Science, 8(20), 797-811. Available at: https://doi.org/10.1287/orsc.1080.0415.

Jensen, S. M., Luthans, K. W., Lebsack, S. A., \& Lebsack, R. R. (2005). Optimism and employee performance in the banking industry. Journal of Applied Management and Entrepreneurship, 12(3), 73.

Kirca, A. H., Ramachandran, S., \& Bearden, W. O. (2005). Market orientation: A meta-analytical review and assessment of its antecedents and impact on performance. Journal of Marketing, 69(6), 24-41. Available at: https://doi.org/10.1509/jmkg.69.2.24.60761.

Lavie, D., Stettner, U., \& Tushman, M. L. (2010). Exploration and exploitation within and across organizations. Academy of Management Annals, 4(32), 109-155. Available at: https://doi.org/10.1080/19416521003691287. 
Levinthal, D. A., \& March, J. G. (1993). The myopia of learning. Strategic Management Journal, 14(S2), 95-1 12.

Lubatkin, M. H., Simsek, Z., Yan, L., \& Veiga, J. F. (2006). Ambidexterity and performance in small- to medium-sized firms: The pivotal role of top management team behavioral integration. Journal of Management, 32(5), 646- 672. Available at: https://doi.org/10.1177/0149206306290712.

March, J. G. (1991). Exploration and exploitation in organizational learning. Organization Science, 2(6), 71-87.

Marino, K. E. (1996). Developing consensus on firm competencies and capabilitie. Academy of Management Executive, 1O(3), 40-51. Available at: https://doi.org/10.5465/ame.1996.9704111473.

Markides, C., \& Charitou, C. D. (2004). Competing with dual business models: A contingency approach. Academy of Management Executive, 18(7), 22-36. Available at: https://doi.org/10.5465/ame.2004.14776164.

Miles, R. E., Snow, C. C., Meyer, A. D., \& Coleman, H. J. J. (1978). Organisational strategy, structure, and process. The Academy of Management Reviere, 3(6), 546-562. Available at: https://doi.org/10.2307/257544.

Noble, C. H., Sinha, R. K., \& Kumar, A. (2002). Market orientation and alternative strategic orientations: A longitudinal assessment of performance implications. Journal of Marketing, 66(4), 25-39. Available at: https://doi.org/10.1509/jmkg.66.4.25.18513.

O'Reilly, C. A., \& Tushman, M. L. (2008). Ambidexterity as a dynamic capability: Resolving the innovator's dilemma. Research in Organizational Behavio, 28(6), 185-206. Available at: https://doi.org/10.1016/j.riob.2008.06.002.

O'Regan, N., \& Ghobadian, A. (2005). Innovation in SMES: The impact of strategic orientation and environmental perceptions. International Journal of Productivity and Performance Management, 54(5), 81-97. Available at: https://doi.org/10.1108/17410400510576595.

Paladino, A. (2008). Financial champions and masters of innovation: Analyzing the effects of balancing strategic orientations. Journal of Product Innovation Management, 26(6), 616-626.

Raisch, S., \& Birkinshaw, J. (2008). Organizational ambidexterity: Antecedents, outcomes, and moderators. Journal of Management, 34(3), 375-409.

Smith, W. K., \& Tushman, M. L. (2005). Managing strategic contradictions: A top management model for managing innovation streams. Organization Science, $16(3), 522-536$.

Tushman, M. L., \& O'reillyIii, C. A. (1996). Ambidextrous organizations: Managing evolutionary and revolutionary change. California Management Review, 6(38), 8-30. 